\title{
Impact of Insurgence on the Agricultural Development in Nigeria
}

\author{
O. Ojogho ${ }^{1}$ and R. A. Egware ${ }^{2}$ \\ Received : $27^{\text {th }}$ May 2015 / Accepted : 27th October 2015
}

\begin{abstract}
Low agricultural production and productivity in Nigeria over the years compared to leading countries like Malaysia, Thailand, Indonesia, and Brazil have been largely ascribed to low fertilizer usage, low utilization of improved seed, inadequate government expenditure and the inability to compete with other sectors. The issues of environmental sustainability, capital accumulation, foreign exchange earnings ability and well-being vis-á-vis production, productivity and agricultural development are rarely considered. The study examined the impact of insurgence on the agricultural development in Nigeria using secondary time-series data collected on Nigerian agricultural share of GDP, infant mortality rate, $\mathrm{CO}_{2}$ emission from fuel combustion and level of food production as proxies for agricultural transformation for the years, 1960-2011 while Nigerian civil war, Boko-Haram, Niger-Delta, Fulani herdsmen insurgences were used as proxies for insurgence. The data were analysed using the Vector Error Correction Model (VECM) after testing for stationarity, co-integration and lag selection using the Augmented Dickey-Fuller (ADF), Johansen and the Schwarz's Bayesian Information Criterion (SBIC) statistics respectively. The results from the VECM showed that a unit decrease in previous year food production level would increase the share of agriculture to GDP by $4.26 \%$ the following year while a shift from noninsurgence to insurgence in any year by Boko-Haram, Niger-Delta and Fulani herdsmen reduced the share of agriculture to GDP by $17.56 \%, 19.45 \%$ and $17.47 \%$ respectively. A similar shift from non-insurgence to insurgence in any year by Boko-Haram and Fulani herdsmen insurgences reduced food production level, on average, by 10.21 and 4.69 tonnes respectively while a shift from non-insurgence to insurgence in any year by Niger-Delta crisis and Fulani herdsmen increased $\mathrm{CO}_{2}$ emission, on average, by about $5 \%$ and $8 \%$ respectively. It is inferred, from the results, that agricultural development should be all-embracing since its component elements have a long-run equilibrium relationship, that insurgence indirectly impact on agricultural development through its effect on the change in food production level, the share of agriculture to GDP, $\mathrm{CO}_{2}$ emission from fuel combustion and infant mortality, and that attempt at ignoring the insurgence by any sect from any region, whether religious, cultural, or communal is also a threat to agricultural development.
\end{abstract}

Keywords: VECM, insurgence, productivity, Eigen-value, trace

\section{INTRODUCTION}

Nigeria is a populous Black African nation, blessed with population of over 160 million people, with wide geographical spread across 36 States and a Federal Capital Territory (Akhemonkhan, et al, 2012). Low agricultural production and productivity in Nigeria over the years compared to leading countries like Malaysia, Thailand, Indonesia, and Brazil have been largely ascribed to low fertilizer usage, low utilization of improved seed, inadequate government expenditure and the inability to compete with other sectors (Olatunbosun,

2 Department of Agricultural Economics, Faculty of Agriculture and Agricultural Technology, Benson Idahosa 
2005). The Federal Government of Nigeria through the Federal Ministry of Agriculture and Rural Development (FMARD), in a bid to revamp the agriculture sector, ensure food security, diversify the economy and enhance foreign exchange earnings, embarked on Agricultural Transformation Agenda. This transformation agenda focused on the development of agricultural value chains, including the provision and availability of improved inputs, increased production and improved productivity, as well as the establishment of staple crop processing zones. Towards achieving a successful agricultural transformation, FMARD is of the opinion that policies regarding agriculture, financial services, industry, and market development need review. That could be said of without a ceteris paribus hypothesis when Nigeria was a household. Agricultural transformation goes beyond production and productivity to include environmental sustainability, capital accumulation, foreign exchange earnings ability and well-being.

Nigeria was one of the relatively secured nations in West African sub-region until recently, when the nation suddenly metamorphosed into an abode of serial bombing, hostage-taking, armed robbery, cold-blooded killings and ethnoreligious conflicts traceable to militant groups with conflicting ideological, socio-economic, political and religious agenda (Akhemonkhan et al, 2012). Fwatshak and Larab (2004) posit that since independence, not a single decade has passed without at least one major civil crisis in Nigeria. It experienced the Western Region political crises in 1960s while the last three to four decades also witnessed some of the worst civil and sectarian crises. Cases in point include incessant military coups, and a fratricidal civil war between 1967 and 1970, the Maitasine riots, starting in Kano and spreading to most parts of Northern Nigeria in the 1980s, ethno-religious crises in Kafanchan and Zango Kataf both in Southern Kaduna in 1987 and 1992, and the June 12, 1993 post-election crises, the Niger-
Delta insurgence, Bakasi Boy, O'odua People's Congress, the current Boko-Haram and Fulani herdsmen insurgences (Darmer, 2004; Albert, 2005; and Tella, 2012). The resultant loss of lives, rising budgetary spending on security, and destruction of valuable government facilities portend devastating consequences for sustainable economic development in the country. Could low agricultural production be tied to these? What possible effects have all these on the Agricultural development in the country? This study, therefore, examined the impact of insurgence on Nigerian agricultural development.

\section{METHODOLOGY}

The data used for the study were mainly secondary, and covered a 56-year annual time-series data for the period 1960-2011 on annual Gross Domestic Product (GDP), Food Production level, carbon (IV) oxide $\left(\mathrm{CO}_{2}\right)$ emission from gaseous fuel consumption and Infant Mortality rate of Nigeria as the measures for foreign exchange earnings ability, capita formation, environmental sustainability and well-being respectively. The data were derived from Central Bank of Nigeria (CBN) statistical bulletin (CBN, 2012) and Food and Agriculture Organaization (FAO) Year Book (2013) and World Development Bank indicators bulletin (2012). National insurgences, as exogenous variables were dummied for the different insurgence in the country since 1960. Such insurgences, included in the study, were the Nigerian civil war, Ethno-religious crisis, NigerDelta, Boko-Haram sect insecurity challenge and the Fulani herdsmen of national concern. The insurgences were dummied with value 1 for the years they occurred and 0 otherwise. The Augmented Dickey-Fuller (ADF) unit-root test was used to test for non-stationarity, Cointegration techniques were used to establish valid relationship among the endogenous variables while the relationship was tested 
using Johansen co-integration test (Hai et.al, 2004) while number of lags was selected using the Schwarz's Bayesian Information Criterion (SBIC). The dynamic model underlying the equation was written, in generic form, as a Vector Error Correction Model (VECM), with four equations, one for each of the endogenous variables as:

$$
\Delta Z_{t}=\sum_{j=1}^{p-1} \varphi_{j} \Delta Z_{t-j}+\gamma^{\dagger} Z_{t-1}+x_{t}+\mu_{t}
$$

where is a column vector of four variables and represents the exogenous variables The $\varphi_{j}=$ $[j=1, \ldots,(p-1)]$ are a set of $(4 \times 4)$ matrices of parameters on the dynamic terms of the model, where the preset lag-length of the model is $p$. Attention was focused on the long-run part of the VECM, where $\gamma^{*}$ is the co-integrating vectors respectively, and $\gamma$ is $n \times r$ matrix to reflect the reduced rank of the system, where it was implicitly assumed that there are $r<n$ cointegrating vectors in the model, $\mu_{\mathrm{t}}$ as a vector of white-noise error terms, with $\mu_{t} \sim N(0, \sigma)$ and Where $\varphi_{j}=-\sum_{i-j+1}^{\mathrm{p}} A_{i}$ and $-\gamma^{*}=I-\sum_{\mathrm{j}=1}^{p} A_{i}$, $j=1,2, \ldots, p-1$ from the corresponding VAR process of finite order $p$, given as $z_{t}=\sum_{j=r}^{p} A_{j} z_{t}$ ${ }_{j}+x_{t}+\mu_{t}$. The Vector Error Correction Model was used because the time series were not stationary in their levels but in their first difference, and co-integrated. The VECM was explicitly written as:

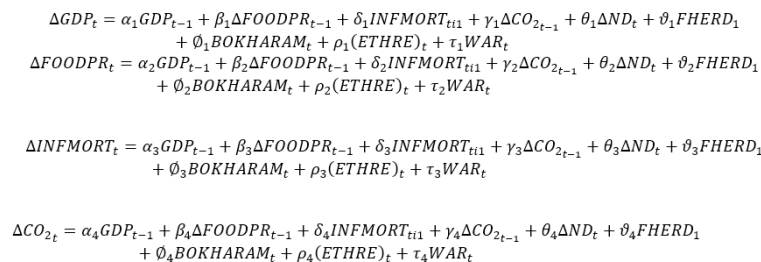

\section{RESULTS AND DISCUSSION}

The ADF statistics for the variables at level form and first difference are shown in Table 01 . The ADF statistic values for the variables at their level form were lower than the critical values at $1 \%, 5 \%$ and $10 \%$, so that the null hypothesis that they have unit root at level form is rejected. However, the ADF statistic values for the variables at their first difference were greater than the critical values at $1 \%, 5 \%$ and $10 \%$, so that the null hypothesis that they have unit root at first difference is not rejected. Augmented Dickey-Fuller (ADF) test for the variables indicate that all variables are nonstationary at level form but stationary at first difference. This indicates that the variables are integrated, at least, of order one $I(1)$ and any attempt to specify the equation in the level form of the series will be inappropriate and may lead to the problem of spurious regression. In particular, the results of econometric analysis at the level of the series may not be suitable for policy making.

The Johansen trace statistic test and maximum likelihood test is presented in Table 02. The results showed that the trace values at both none and at most one of 55.48 and 30.21 respectively were higher than their corresponding critical values at 5\% level of significance. This implies that the null hypothesis of no co-integrating relationship can be rejected at both the 5\% and $1 \%$ levels of significance for GDP, Infant mortality, $\mathrm{CO}_{2}$ emission and food production level in Nigeria. Trace test indicated two co-integrating equations at the 5\% level. Similarly, the Johansen maximum Eigen statistics at both none and at most 1 of 25.27 and 22.81 respectively were, higher than their corresponding critical values at 5\% level of significance. Maximum Eigen-value test also indicated two co-integrating equations at the 5\% level. This also implied that the null hypothesis of no co-integrating relationship can be rejected at both the $5 \%$ and $1 \%$ levels of significance for GDP, Infant mortality, $\mathrm{CO}_{2}$ emission and food production in Nigeria, implying that a form of long-run equilibrium relationship exist among GDP, Infant mortality, $\mathrm{CO}_{2}$ emission and food production in Nigeria, and are integrated at order $I(2)$. This also implies that there exists an error-correction model that describes the shortrun dynamics consistently with the long-run relationship. 
Table 01: Augmented-Dickey-Fuller (ADF) Unit Root Test

\begin{tabular}{|c|c|c|c|c|}
\hline \multirow[t]{3}{*}{ Variable } & \multicolumn{4}{|c|}{ Augmented-Dickey-Fuller } \\
\hline & \multicolumn{2}{|c|}{ With Intercept } & \multicolumn{2}{|c|}{ With Intercept and Trend } \\
\hline & Level & First Difference & Level & First Difference \\
\hline GDP & 0.925 & $-6.907^{*}$ & -0.188 & $-7.243^{*}$ \\
\hline $\mathrm{CO}_{2}$ & -1.679 & $-7.082^{*}$ & -3.152 & $-7.010^{*}$ \\
\hline Infant Mortality & 0.486 & $-4.311^{*}$ & -1.298 & $-6.380^{*}$ \\
\hline Food Production & 2.388 & $-7.723^{*}$ & -1.147 & $-9.146^{*}$ \\
\hline Niger-Delta Crisis & -2.313 & $-9.628^{*}$ & -6.928 & $-6.888^{*}$ \\
\hline War & -2.773 & $-3.016^{*}$ & & $-6.861^{*}$ \\
\hline
\end{tabular}

*That the null hypotheses that the series contain a unit root are rejected at $1 \%$ significance level.

Table 02: Unrestricted Co-integration Rank Test (Trace and Maximum Eigen-value)

\begin{tabular}{cccccccc}
\hline $\begin{array}{c}\text { Hypothesized } \\
\text { No. of CE(s) }\end{array}$ & Eigenvalue & $\begin{array}{c}\text { Trace } \\
\text { Statistic }\end{array}$ & $\begin{array}{c}0.05 \text { Critical } \\
\text { Value }\end{array}$ & Prob. ${ }^{* *}$ & $\begin{array}{c}\text { Max-Eigen } \\
\text { Statistic }\end{array}$ & $\begin{array}{c}0.05 \text { Critical } \\
\text { Value }\end{array}$ & Prob. $^{* *}$ \\
\hline None & 0.415892 & 55.48356 & 40.17493 & 0.0008 & 25.27045 & 24.15921 & 0.0353 \\
At most 1 & 0.384473 & 30.21311 & 24.27596 & 0.0080 & 22.80803 & 17.79730 & 0.0081 \\
At most 2 & 0.140940 & 7.405081 & 12.32090 & 0.2866 & 7.140083 & 11.22480 & 0.2376 \\
At most 3 & 0.005622 & 0.264998 & 4.129906 & 0.6667 & 0.264998 & 4.129906 & 0.6667 \\
\hline
\end{tabular}

* denotes rejection of the hypothesis at the 0.05 level, **MacKinnon-Haug-Michelis (1999) p-values

The Vector Error Correction Model parameters and their associated standard errors and $\mathrm{t}$-statistics are presented in Table 03. The result showed that in co-integrating equation 1 , only Infant mortality and food production were statistically significant at $1 \%$ and $5 \%$ levels respectively while in co-integrating equation 2 , infant mortality, previous year food production level and $\mathrm{CO}_{2}$ were statistically significant but all at $5 \%$ level. The negative sign of the coefficient 0.005603 of food production level in the first co-integrating equation implies a tendency to reduce (correct) large differences in the food production level through an upward adjustment, leading to increasing short-run food production by about 0.006 tonne but a decline in the long-run food production level. Contrary to food production level, the positive sign of the coefficient 0.001384 of infant mortality in first co-integrating equation implies a tendency to correct large differences in infant mortality through a downward adjustment, leading to decreasing short-run infant mortality by about
1 in every 1000 birth but an increase in the long-run. However, the reverse is the case in the second co-integrating equation for food production level and infant mortality with downward and upward adjustment respectively, leading to respective decreasing and increasing short-run in food production level and infant mortality by 0.024 tonne and about four in every 100 birth but increasing and decreasing in the long-run. For $\mathrm{CO}_{2}$ in the second co-integrating equation, the positive sign of the coefficient 0.017681 implies a tendency to correct large differences in infant mortality through a downward adjustment, leading to decreasing short-run $\mathrm{CO}_{2}$ by about $0.02 \%$ but an increase in the long-run. In the GDP equation, previous year food production level and insurgence from Boko-Haram, Niger-Delta and Fulani herdsmen with respective coefficients of $-4.26,-17.56$, -19.45 and -17.47 statistically affected the share of agriculture to GDP at $1 \%, 5 \%, 1 \%$ and $1 \%$ levels of significance respectively. 
Table 03: Estimates of the Co-integration Equation and Vector Error Correction Model

\begin{tabular}{|c|c|c|c|c|}
\hline & $\mathrm{D}(\mathrm{GDP})$ & D(INFMORT) & $\mathrm{D}(\mathrm{CO} 2)$ & D(FOODPR) \\
\hline \multirow[t]{3}{*}{ CointEq1 } & -0.033752 & $0.001384^{* * *}$ & 0.001096 & $-0.005603 * *$ \\
\hline & $(0.04538)$ & $(0.00040)$ & $(0.00168)$ & $(0.00234)$ \\
\hline & {$[-0.74382]$} & [ 3.48965] & {$[0.65162]$} & {$[-2.39017]$} \\
\hline \multirow[t]{3}{*}{ CointEq2 } & 0.244287 & $-0.004418^{* *}$ & $-0.017681^{* *}$ & $0.024010^{* *}$ \\
\hline & $(0.20987)$ & $(0.00183)$ & (0.00778) & $(0.01084)$ \\
\hline & [ 1.16400$]$ & {$[-2.40898]$} & [-2.27290] & [2.21447] \\
\hline \multirow[t]{3}{*}{$\mathrm{D}(\mathrm{GDP}(-1))$} & 0.280047 & $-0.003546^{*}$ & $0.015879^{*}$ & 0.019950 \\
\hline & $(0.23255)$ & $(0.00203)$ & $(0.00862)$ & $(0.01201)$ \\
\hline & {$[1.20426]$} & {$[-1.74536]$} & [ 1.84221] & [1.66060] \\
\hline \multirow[t]{3}{*}{ D(INFMORT(-1)) } & -9.381258 & $0.658522^{* * *}$ & 1.577901 & 0.463514 \\
\hline & (13.6453) & $(0.11923)$ & $(5.05780)$ & $(0.70494)$ \\
\hline & {$[-0.68751]$} & [ 5.52310] & {$[0.31197]$} & {$[0.65752]$} \\
\hline \multirow[t]{3}{*}{$\mathrm{D}(\mathrm{CO} 2(-1))$} & -3.782723 & 0.019830 & 0.245333 & -0.064705 \\
\hline & (4.14399) & $(0.03621)$ & $(0.15360)$ & $(0.21409)$ \\
\hline & {$[-0.91282]$} & {$[0.54765]$} & [ 1.59719] & {$[-0.30224]$} \\
\hline \multirow[t]{3}{*}{ D(FOODPR $(-1))$} & $-4.262452 * * *$ & -0.013699 & 0.053301 & $-0.374658 * *$ \\
\hline & (1.10034) & $(0.02709)$ & $(0.11492)$ & $(0.16017)$ \\
\hline & {$[-3.8756]$} & {$[-0.50568]$} & {$[0.46382]$} & {$[-2.33914]$} \\
\hline \multirow[t]{3}{*}{ ETHRE } & 58.62064 & 0.250388 & -0.746030 & 1.817173 \\
\hline & (43.1091) & $(0.37668)$ & (1.59790) & $(2.22709)$ \\
\hline & [ 1.35982] & {$[0.66473]$} & {$[-0.46688]$} & [ 0.81594] \\
\hline \multirow[t]{3}{*}{ BOKHARAM } & $-17.5648 * *$ & $1.677113^{*}$ & 1.035623 & $-10.20569^{*}$ \\
\hline & $(8.413)$ & $(0.88613)$ & (3.75903) & (5.23919) \\
\hline & {$[-2.0878]$} & {$[-1.89262]$} & {$[-0.27550]$} & [ 1.94795] \\
\hline \multirow[t]{3}{*}{$\mathrm{ND}$} & $-19.44645^{* * *}$ & $1.483331^{* *}$ & $4.568898^{*}$ & -2.964529 \\
\hline & $(6.3263)$ & $(0.57081)$ & $(2.42141)$ & (3.37487) \\
\hline & {$[-3.0739]$} & [2.59865] & {$[-1.88688]$} & {$[-0.87841]$} \\
\hline \multirow[t]{3}{*}{ FHERD } & $-17.4688^{* * *}$ & 0.763116 & $8.148013^{* *}$ & $-4.691009 * * *$ \\
\hline & (4.8579) & $(0.78516)$ & (3.33070) & (1.64221) \\
\hline & {$[-3.5960]$} & [ 0.97192] & {$[-2.44634]$} & {$[-2.85652]$} \\
\hline \multirow[t]{3}{*}{ WAR } & 23.62436 & 0.478650 & -0.435803 & -1.037702 \\
\hline & (54.4354) & $(0.47565)$ & (2.01772) & (2.81222) \\
\hline & {$[0.43399]$} & [ 1.00631$]$ & {$[-0.21599]$} & {$[-0.36900]$} \\
\hline R-squared & 0.274678 & 0.897439 & 0.402158 & 0.222024 \\
\hline Adj. R-squared & 0.073200 & 0.868950 & 0.236091 & 0.005919 \\
\hline Sum sq. resids & 335871.9 & 25.64363 & 461.4586 & 896.4185 \\
\hline S.E. equation & 96.59076 & 0.843992 & 3.580265 & 4.990041 \\
\hline F-statistic & 1.363314 & 31.50098 & 2.421661 & 1.027390 \\
\hline Log likelihood & -275.2370 & -52.45258 & -120.3699 & -135.9742 \\
\hline Akaike AIC & 12.18030 & 2.700110 & 5.590207 & 6.254222 \\
\hline Schwarz SC & 12.61331 & 3.133123 & 6.023220 & 6.687235 \\
\hline Mean dependent & 21.03915 & -3.387234 & 0.408936 & 1.396596 \\
\hline S.D. dependent & 100.3327 & 2.331413 & 4.096325 & 5.004876 \\
\hline Log likelihood & & -580.7175 & & \\
\hline Akaike information criterion & & 26.92415 & & \\
\hline Schwarz criterion & & 28.97112 & & \\
\hline
\end{tabular}

*significant at $10 \%$ level, ** significant at $5 \%$ level, *** significant at $1 \%$ level, standard Error in parenthesis and t-Statistics in brackets; GDP is Gross Domestic Product; $\mathrm{CO}_{2}$ is carbon (IV) oxide; FOODPR is Food Production Level; INFMORT is Infantmortality; ETHRE is Ethno-religion; BOKHARAM is Boko-Haram; ND is Niger-Delta; FHERD is Fulani Herdsmen. D in front of each of the independent variables implies that the variable is differenced once before becoming stationary. 
This means that a unit change in previous year food production level would reduce the share of agriculture to GDP the following year by $4.26 \%$ while a shift from non-insurgence to insurgence in any year by Boko-Haram, NigerDelta and Fulani herdsmen would reduce the share of agriculture to GDP the following year by $17.56 \%, 19.45 \%$ and $17.47 \%$ respectively in the short-run. The effect of the change in previous year food production level on share of agriculture on GDP could be attributed to the reduction on food production by insurgence the year before. In the equation explaining the change in infant mortality, unit change in the immediate past year GDP and infant mortality as endogenous variables significantly affected infant mortality while Boko-Haram and the Niger-Delta insurgence significantly affected infant mortality. The coefficient of the immediate past year GDP and infant mortality were -0.004 and 0.659 respectively while Boko-Haram and Niger-Delta insurgence had coefficients of -1.677 and 0.571 respectively. These mean that 1000 unit decrease in immediate past year GDP would increase infant mortality by four in every 1000 children under the age of five years while 10 units increase in the immediate past year infant mortality would increase mortality of children under the age of five years by seven in every 1000 birth in the short-run. Also a shift from non-insurgence to insurgence of Boko-Haram in the current year would increase mortality of children under the age of five years by $2 \%$ on average while a similar move from non-insurgence to insurgence of NigerDelta in the current year would increase it by $1 \%$ on the average in the short-run. In the equation explaining the $\mathrm{CO}_{2}$ emission from fuel consumption, only Niger-Delta and Fulani herdsmen insurgences significantly affected the $\mathrm{CO}_{2}$ emission from fuel consumption.

The coefficient of the current year NigerDelta and Fulani herdsmen insurgences were -4.569 and 8.148 respectively. These mean that a shift from non-insurgence to insurgence of Niger-Delta in the current year would reduce $\mathrm{CO}_{2}$ emission by $4.57 \%$ on the average while a similar move from non-insurgence to insurgence of Fulani herdsmen in the current year would increase it by $8.15 \%$ on the average in the short-run. In the equation explaining food production, only Boko-Haram and Fulani herdsmen insurgences, among the insecurity challenges statistically had significant effect on the change in food production. The coefficients of the current year Boko-Haram and Fulani herdsmen insurgences were -10.206 and -4.691 respectively. These mean that a shift from noninsurgence to insurgence of Boko-Haram and Fulani herdsmen in the current year would reduce food production by 10.21 and 4.69 tonnes on average respectively in the short-run. There was no statistical evidence that the endogenous variables adjust to any deviation from long-run equilibrium with respect to the war, so that it could be treated as weakly exogenous.

\section{CONCLUSION}

The study examined the effect of insurgence on the agricultural development in Nigeria using Vector Error Correction Model (VECM) on Nigerian GDP, infant mortality rate, $\mathrm{CO}_{2}$ emission and food production as proxies for agricultural transformation on Boko-Haram, Niger-Delta, Fulani herdsmen insurgences and the prominent Nigerian civil war as proxies for insurgence. It is inferred, from the results, that agricultural development should be allembracing since it component elements have a long-run equilibrium relationship. Insurgence indirectly impact on agricultural development through its effect on the change in food production level, the share of agriculture to GDP, $\mathrm{CO}_{2}$ emission from fuel combustion and infant mortality, and that attempt at ignoring the insurgence by any sect from any region, whether religious, cultural, or communal is a threat to agricultural development. 


\section{REFERENCES}

Akhemonkhan, I. A., Raimi, L. and Ogunjirin, O. D. (2012). Corporate Social Responsibility and Entrepreneurship (CSRE): Antidotes to Poverty, Insecurity and Underdevelopment in Nigeria. Presented at the $6^{\text {th }}$ International Conference held in Universiti de Lome, Togo from November 1-2.

Albert O. I. (2005). Terror as a Political Weapon: Reflections on the Bomb Explosions in Abacha's Nigeria. IFRA Ibadan, Special Research Issue 1, pp.37-56.

Central Bank of Nigeria, CBN (2012). Annual Report and Statement of Accounts. CBN, Abuja, Nigeria.

Darmer, M. K. B., Baird, R. M. and Rosenbaum, S. E. (2004) Civil Liberties versus National Security In A Post 9/11 World, New York, Prometheus Books.

Food and Agriculture Organization of the United Nations, FAO (2013). The state of food and agriculture-bio-fuels: prospects, risks, and opportunities. Rome: FAO.

Fwatshak, S. U. and Larab, A. (2004). "Political Assassinations and Nigeria's Political Quagmire: A Historical Anthology in Sapha" A Journal of Historical Studies, 1(2 \& 3)

Hai, L. T. D; Lutz, C. and Praagman, C. (2004). Rice Marketing Integration in the Mekong River Delta: The Successful Libralization of the Domestic Foos Market in Vietnam. Research Report 04B10, University of Groningen, Research Institute, Systems, Organization and Management (SOM)

MacKinnon, J. G., Haug, A. A. and Michelis, L. (1999). "Numerical Distribution Functions of Likelihood Ratio Tests for Cointegration," Journal of Applied Econometrics, 14, 563- 577.

Olatunbosun, D. (2005). Nigeria’s Neglected Rural Majority, Ibadan: Oxford University Press.

Raimi, L. and Ogunjirin, O. D. (2012). Fast-tracking sustainable economic growth and development in Nigeria through international migration and remittances, Humanomics, 28(3) $209-219$.

Tella, S. A. (2012). Cost of Corruption on the Nigerian Economy. Lecture presented at the 2012 Independent Day Lecture organized by The Muslim Congress on October 6, at MKO Abiola International Stadium, Abeokuta, Ogun State.

World Development Indicators (2012). (database).http://data.worldbank.org/data-catalog/worlddevelopment-indicators. Washington, DC: World Bank. 